\title{
Impact of Salinity Stress on Germination and Growth of Pea (Pisum sativum L) Plants
}

\author{
Amal F Ehtaiwwesh and Munira J Emsahel \\ Department of plant science, University of Zawia, Libya
}

Received: 05 July 2020/ Accepted: 29 August 2020

Doi: https://doi.org/10.54172/mjsc.v35i2.319

\begin{abstract}
The aim of the present study was to evaluate the effects of salinity stress on germination and growth of pea (Pisum sativum L) plants. A laboratory experiment was conducted to evaluate the effect of salinity stress on germination and growth of pea Pisum sativum L plant. Seeds of pea were sown in Petri dishes and pots and treated with four different levels of salinity $(0,50,100$, and $150 \mathrm{mM} \mathrm{NaCl}$ ) with completely randomized designs in four replications. Results revealed that seeds of pea were able to germinate at low salinity levels $(\mathrm{NaCl} 50 \mathrm{mM} \mathrm{NaCl})$ without a significant decrease in germination and growth traits, at the same time as a severe decrease in those traits were recorded at higher levels of salinity $(100$ and $150 \mathrm{mM} \mathrm{NaCl})$. The results indicated that seed germination and seedling establishment were inhibited due to the decrease of water potential, which results in the decline in water uptake by seeds, and seed germination was prevented by a high level of salinity stress $(150 \mathrm{mM} \mathrm{NaCl})$. The results pointed out that germination percentage (GP), mean daily germination (MDG), germination speed (GS), and vigor index (SVI) varied under moderate and high salinity levels. All the studied parameters were reduced with increasing the $\mathrm{NaCl}$ level. The max and min GP, MDG, GS, and SVI were observed under control conditions ( $0 \mathrm{mM} \mathrm{NaCl})$ and highest salinity level $(150 \mathrm{mM} \mathrm{NaCl})$ respectively. The same trend was seen in plant growth traits including: plant height, branch number, leaf number, leaf area, and shoot fresh and dry weight. The results provided important reference information for research on the impact of salinity on germination and growth of pea.
\end{abstract}

Keywords: Pea (Pisum sativum L.); Salinity Stress; Germination; Growth; Seedling Vigor Index.

\section{INTRODUCTION}

Salt injure is one of the most important abiotic stress that affects plant productivity worldwide. About $20 \%$ of the global land area and over $50 \%$ of agricultural irrigated land is saltaffected soils (Cheng et al., 2016). It is also estimated that about $50 \%$ of agricultural land will be affected by salt in 2050 (Mahajan and Tuteja, 2005; Yan et al., 2005). Soils become saline when the soil salt concentration reaches about 40mM NaCl (Munns and Tester, 2008). The majority of crops are highly susceptible to saline soil. Crops are typically sown within the top $10-15 \mathrm{~cm}$ layer of top soils. These layers are more saline than lower layers (Esechie, 1995).
Therefore, seeds show irregular germination and poor seedling development. In most crop plants, the yields start decreasing even at fairly low salinity in soil with electrical conductivity of (ECse $>1 \mathrm{dS} / \mathrm{m}$ ) (Chinnusamy et al. 2005). Saline soils affect the growth of crop plants in two different ways (I) raising the osmotic pressure of soil solution, which results in an additional decrease in the physiological availability of water to the plant and, (II) the accumulation of toxic quantities of various ions within the plant (Hayward and Wadleigh, 1949). Salinity decreases seeds' ability to absorb water and causes a decrease in germination and plant growth, which leads to 
changes in plant metabolic processes (Munns, 1993; Munns, 2002). Seed germination and seedling growth are the most sensitive stages to salt stress (Bhattacharjee, 2008; Hubbard et al., 2012). Salt stress affects seed germination through osmotic stress, ion-specific effects, and oxidative stress (Hayward and Wadleigh, 1949). Salt stress influences the seed germination and plant growth of many plants. Many studies found that seed germination and early establishment of seedlings were inhibited by increasing salinity stress in different crops such as - wheat (Sadak, 2016; Mujeeb-Kazi et al., 2019), cabbage (Sarker et al., 2014; Yan, 2015), maize (Konuşkan et al., 2017), and cowpeas (Abdel-Haleem and El-Shaieny, 2015),

Pea (Pisum sativum L.) plant is an important winter season vegetable legumes grown in Libya and the Mediterranean region and used as a source of protein vitamins, minerals, salts, and antioxidants (Nuttonson, 1961; Noreen and Ashraf, 2009). It's economically grown and used for dry grain or fresh fruit (Kaya et al., 2002). Also, the pea plant is grown as a forage crop for farm animals, as a green compost crop for improving soil, and as a cover crop for reducing soil erosion (Wolde and Adamu, 2018).

Pea plants can be grown on a wide range of soil types, from light sandy to heavy clay (McKay et al., 2003). Pea is a legume and has the inherent ability to obtain its nitrogen requirement from the atmosphere by forming a symbiotic relationship with Rhizobium bacteria in the soil (Schatz and Endres, 1999). The pea plant has quite a short growing season and uses less water than many other broadleaf crops (Johnson et al., 2002). However, the plant has been accounted as a salt-sensitive plant as compared with other legumes, such as broad bean, common bean, and soybean (Zahran, 1999; Khan et al, 2015). Nevertheless, the effect of salinity on growth and yield of peas has been investigated in many studies (Hernhdeza et al., 1995; Martí, 2011; Pandolfi,
2012; Shahid, 2012; Husen et al., 2016; Wang et al., 2016; Desoky et al, 2017), however the impact of salinity on germination and seedling growth has not been well investigated and the relative importance of the effects of salt stress on seed germination of peas is not clear. Therefore, the aim of the present study was to evaluate the effect of salinity on germination and growth of pea plants.

\section{MATERIAL AND METHODS}

This study was carried out at the Department of Plant Science, University of Zawia. Pea seeds were obtained from the local market. Salinity concentrations were $(0,50,100$, and $150 \mathrm{mM}$ $\mathrm{NaCl}$ ) prepared using $\mathrm{NaCl}$ and fresh water. The electrical conductivities of $\mathrm{NaCl}$ solutions were 4.4, 8.3, and $15.3 \mathrm{dS} \mathrm{m}^{-1}$, and fresh water served as a control. For this research, a pair of experiments were conducted. A laboratory experiment to evaluate the effect of salinity stress on seed germination of peas, and a pot experiment to evaluate the influence of salinity stress on seedling growth of pea plants.

Experiment I: Pea seeds were first sterilized for $5 \mathrm{~min}$ with $5 \%$ commercial bleach (Pandolfi e al., 2012), then thoroughly washed with distilled water. Germination tests were conducted in Petri dishes (containing one Whatman filter papers with $20 \mathrm{ml}$ of respective test solutions) with four treatments by four replications (10 seeds per replication). The Whatman filter papers were replaced every 2 days to prevent the accumulation of salts. Seeds were allowed to germinate at room temperature and in darkness for 10 days. During this period, the Petri dishes were monitored daily, and $5 \mathrm{ml}$ of the appropriate solution was added to the Petri dishes. A seed was considered to have germinated when the emerging radicle was $10 \mathrm{~mm}$ long (Cokkizgin, 2013).

Experiment II: A pot experiment was conducted to investigate the effect of salinity on the growth of pea plants. Pea seeds were 
grown in pots filled with loamy soil, which was collected from the soil surface $(0-10 \mathrm{~cm})$. The soil was air-dried and passed through a $5-\mathrm{mm}$ mesh screen, and filled in small plastic pots without a leaching possibility. Four pea seeds were sown in each pot and irrigated with fresh water for 10 days. After seedling establishment, only two seedlings of each pot were kept. Pots were then divided into four groups with four replications. Each group represented one saline treatment, which includes $0,50,100$, and $150 \mathrm{mM} \mathrm{NaCl}$. Pots were kept under semi-controlled conditions and irrigated with an appropriate saline solution for 30 days. At the end of the experiment, one plant from each pot was collected and used for data collection.

\section{Data Collection:}

Germination traits: Germinated seeds were counted daily for 10 days, and the number of germinated seeds was recorded every $24 \mathrm{~h}$ for each replicate of the treatment. After 10 days the germination percentage (GP) was calculated using the formula below (Nasri et al., 2011).

\section{$\boldsymbol{G P} \%=(\boldsymbol{N S G} \div \boldsymbol{T N S S}) \times \mathbf{1 0 0}$}

Where NSG is the number of seeds germinated. TNSS is the total number of seeds sown.

The germination speed (GS) was calculated according to the equation given by Rubio-Casal et al. (2003). The number of germinated seeds was recorded every day from sowing, and lasted for 10 days, and was used to calculate GS. The following formula was used to calculate GS:

$$
G S=n 1 / d 1+n 2 / d 2+n 3 / d 3+\cdots
$$

Where $n_{l}$ is the number of seeds germinated in day one of sowing, $d l$ is the number of days taken for germination from the day of sowing. Mean daily germination (MDG) was calculated as per Gairola et al (2011). The following formula was used to calculate MDG:

$M D G=T N G S \div T N D G$

Where $T N G S$ is the total number of germinated seeds and $T N D G$ is the total number of days taken for final germination.
Growth traits: Morphological traits include plant height, number of branches per plant, number of leaves per plant, leaf area, and aboveground fresh biomass weight per plant, and their dry weight. Aboveground fresh and dry biomass weight were subsequently measured from 4 uniform seedlings per each treatment at the seedling stage. The plant height was measured using a measuring ruler from the surface of the soil to the top of the last leaf blade. The leaf area was calculated by measuring each leaf. Each leaf has two leaflets (left, and right), and the traits length (L) and maximum width (W) of leaflets were measured using a measuring ruler. The product of the length times width (LW) of the leaflet was calculated. The fresh weight of aboveground biomass was recorded using a weighing balance and then dried in an oven at $50{ }^{\circ} \mathrm{C}$ till a stable weight had been attained. Subsequently, the aboveground dry weights were recorded using a weighing balance. Using the morphological traits, the salinity tolerance index (STI) and seedling vigor index (SVI) were calculated as follows.

Salinity tolerance index (STI) was calculated according to the equation given by Tregay et al. (2014). STI = Seedling dry weight of $\mathrm{NaCl}$ treated/seedling dry weight in control x 100 .

Seedling vigor index (SVI) was calculated according to the equation given by Abdolil et al. (2013) SVI = Seedling length $(\mathrm{cm}) \mathrm{x}$ germination percentage / 100 .

\section{Statistical analysis:}

The experimental design was completely randomized (CRD) with four replications. Analysis of variance was performed using the generalized linear model (GLM) procedure in SAS 9.4 (SAS Institute Inc., Cary, NC, USA) for seed germination and growth related traits. Separation of means was carried out using the least significant differences (LSD; $P<0.05$ ). The means were compared using Duncan's multiple range test. 


\section{RESULTS}

The Probability values for germination and plant growth traits obtained with SAS PROC GLM are presented in Table 1. The obtained results clearly illustrated that salinity stress induced a significant reduction in germination and growth parameters in pea plants. Significant reduction $(P<0.05)$ was observed in almost all the studied germination and plant growth traits when pea plants were grown under salinity stress. Germination percent, mean daily germination, germination speed, plant height, number of branches, number of leaves, leaf area, fresh and dry branches weight, salinity tolerance index and vigor index were the traits which showed significant differences as shown in Table 2.

Table (1): Probability values of the effects of Salinity (S) on germination and plant growth traits of pea plants.

\begin{tabular}{lr}
\hline \hline Traits & Salinity (S) \\
\hline Germination percent (\%) & 0.0458 \\
Mean daily germination (MDG) & 0.0453 \\
Germination speed & 0.0425 \\
Plant height (cm) & 0.0495 \\
number of branches & 0.0357 \\
number of leaves & 0.0416 \\
Leaf area (cm $\left.{ }^{2}\right)$ & 0.0477 \\
Shoot fresh weight (g) & 0.0504 \\
Shoot dry weight (g) & 0.0370 \\
Salinity tolerance index & 0.0355 \\
Vigor index & 0.0348 \\
\hline \hline
\end{tabular}

Germination traits: Although, the germination percentage and speed of germination were not significantly affected at a low salinity level (50mM NaCl.), however, germination traits including germination percentage, speed of germination, and mean daily germination, decreased gradually with increasing salinity stress levels. Under a salinity level of $150 \mathrm{mM}$ $\mathrm{NaCl}$, germination percentage, speed of germination, and mean daily germination decreased by $37 \%, 45 \%$, and $43 \%$ respectively (Fig 1a, b, and c).

Table (2) The effect of Salinity (S) on germination and plant growth traits of pea plants..

\begin{tabular}{|c|c|c|c|c|}
\hline \multirow{2}{*}{ Traits } & \multicolumn{3}{|c|}{ Salinity Level mM NaCl } & \multirow[b]{2}{*}{150} \\
\hline & 0 & 50 & 100 & \\
\hline $\begin{array}{l}\text { Germination } \\
\text { percent }(\%)\end{array}$ & $95^{\mathrm{a}}$ & $90^{\mathrm{a}}$ & $83^{\mathrm{ab}}$ & $60^{\mathrm{b}}$ \\
\hline $\begin{array}{l}\text { Mean daily } \\
\text { germination }\end{array}$ & $1.5^{\mathrm{a}}$ & $1.3^{\mathrm{ab}}$ & $1^{\mathrm{ab}}$ & $0.8^{\mathrm{b}}$ \\
\hline $\begin{array}{l}\text { Germination } \\
\text { speed }\end{array}$ & $1.9^{\mathrm{a}}$ & $1.6^{\mathrm{a}}$ & $1.4^{\mathrm{ab}}$ & $1^{\mathrm{b}}$ \\
\hline $\begin{array}{l}\text { Plant height } \\
\text { (cm) }\end{array}$ & $14.9^{\mathrm{a}}$ & $13^{\mathrm{a}}$ & $8.6^{\mathrm{ab}}$ & $5.6^{\mathrm{b}}$ \\
\hline $\begin{array}{l}\text { number of } \\
\text { branches }\end{array}$ & $4.5^{\mathrm{a}}$ & $3.5^{\mathrm{ab}}$ & $2^{\mathrm{b}}$ & $1.5^{\mathrm{b}}$ \\
\hline $\begin{array}{l}\text { number of } \\
\text { leaves }\end{array}$ & $10.5^{\mathrm{a}}$ & $8.5^{\mathrm{ab}}$ & $5.5^{\mathrm{bc}}$ & $3.5^{\mathrm{c}}$ \\
\hline Leaf area $\left(\mathrm{cm}^{2}\right)$ & $23^{\mathrm{a}}$ & $19^{\mathrm{ab}}$ & $12^{\mathrm{ab}}$ & $8^{\mathrm{b}}$ \\
\hline $\begin{array}{l}\text { Shoot fresh } \\
\text { weight }(\mathrm{g})\end{array}$ & $4.8^{\mathrm{a}}$ & $4^{\mathrm{ab}}$ & $2.8^{\mathrm{ab}}$ & $2^{\mathrm{b}}$ \\
\hline $\begin{array}{l}\text { Shoot dry } \\
\text { weight }(\mathrm{g})\end{array}$ & $2.6^{\mathrm{a}}$ & $1.9^{\mathrm{ab}}$ & $1.3^{\mathrm{ab}}$ & $0.7^{\mathrm{b}}$ \\
\hline $\begin{array}{l}\text { Salt tolerance } \\
\text { index }\end{array}$ & $100^{\mathrm{a}}$ & $84^{\mathrm{a}}$ & $54^{\mathrm{ab}}$ & $27^{\mathrm{b}}$ \\
\hline Vigor index & $14^{\mathrm{a}}$ & $12^{\mathrm{a}}$ & $7^{\mathrm{ab}}$ & $4^{b}$ \\
\hline
\end{tabular}

* Individual value is the mean of 4 plants under different salinity levels. Values followed by different letters are significantly different according to Duncan's multiple range test $(P<0.05)$.

Growth traits: Growth data presented in Tables 1 and 2 show that plant growth traits were significantly affected $(P<0.05)$ by salinity stress. The data pointed out that under increased salinity levels, the plant height and number of branches per plant was significantly reduced. At a high level of salinity $(150 \mathrm{mM}$ $\mathrm{NaCl}$ ), both traits (plant height and branch number per plant) were reduced by $62 \%$ and $67 \%$ respectively (Fig $2 a$ and $b$ ). 


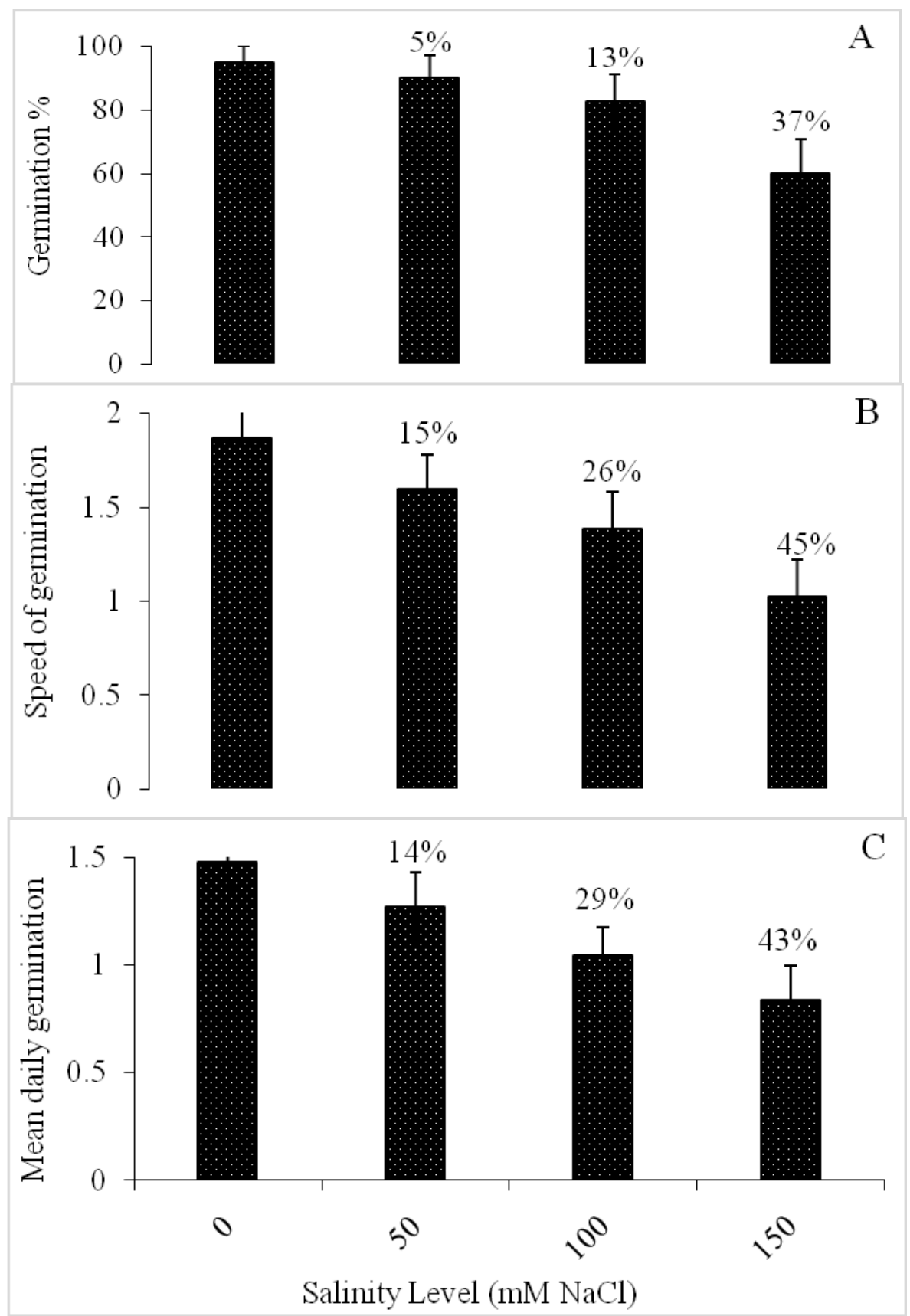

Figure (1) The effects of salinity treatments on (A) germination percentage, (B) speed of germination and (C) mean daily germination of pea plant. Each datum indicates mean value, and vertical lines on top of bars indicate standard error of means $(n=4)$. Values in parenthesis indicates the percent reduction from control.

Raising the salinity level from 50 to $150 \mathrm{mM}$ $\mathrm{NaCl}$ gradually decreased the vigor index. The highest vigor index was observed in control, while salinity at 50,100 , and $150 \mathrm{mM} \mathrm{NaCl}$ decreased the vigor index. A significant decrease in the vigor index was observed at $150 \mathrm{mM} \mathrm{NaCl}$ salinity, which caused a $71 \%$ reduction over the control (Fig 2c). 


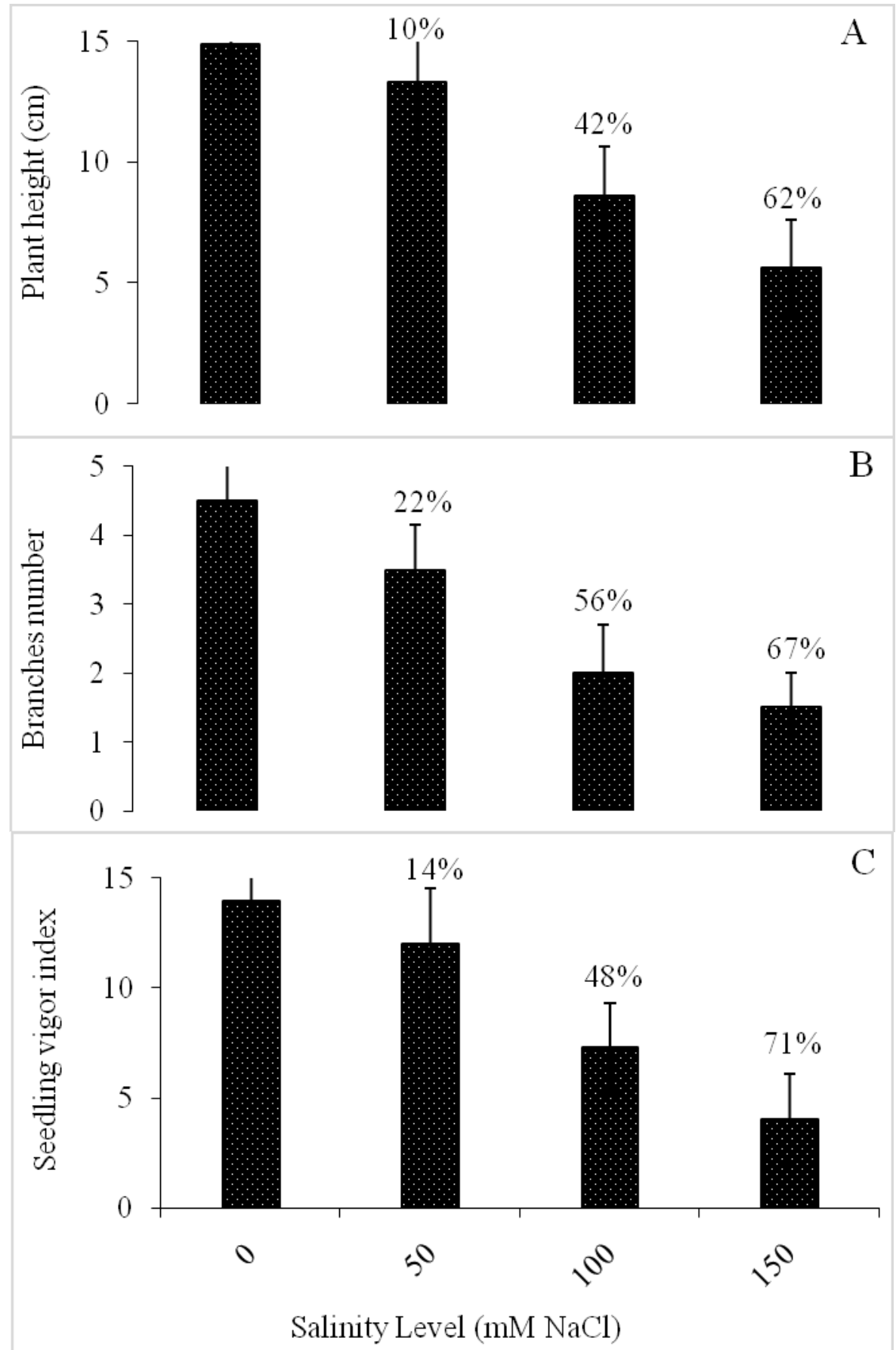

Figure (2): The effects of salinity treatments on (A) plant height (cm), (B) branch number and (C) seedling vigor index of pea plant. Each datum indicates mean value, and vertical lines on top of bars indicate standard error of means $(\mathrm{n}=$ 4). Values in parenthesis indicates the percent reduction from control.

The same reduction tendency was seen in leaf number per plant and leaf area per plant. As shown in Figure $3 a$ and $b$, both traits, leaf number per plant and leaf area per plant, were strongly influenced by the high salinity level.
The percent reduction over the control of leaf number per plant and leaf area per plant were $65 \%$ and $67 \%$ respectively (Fig $3 a$ and $b$ ). 


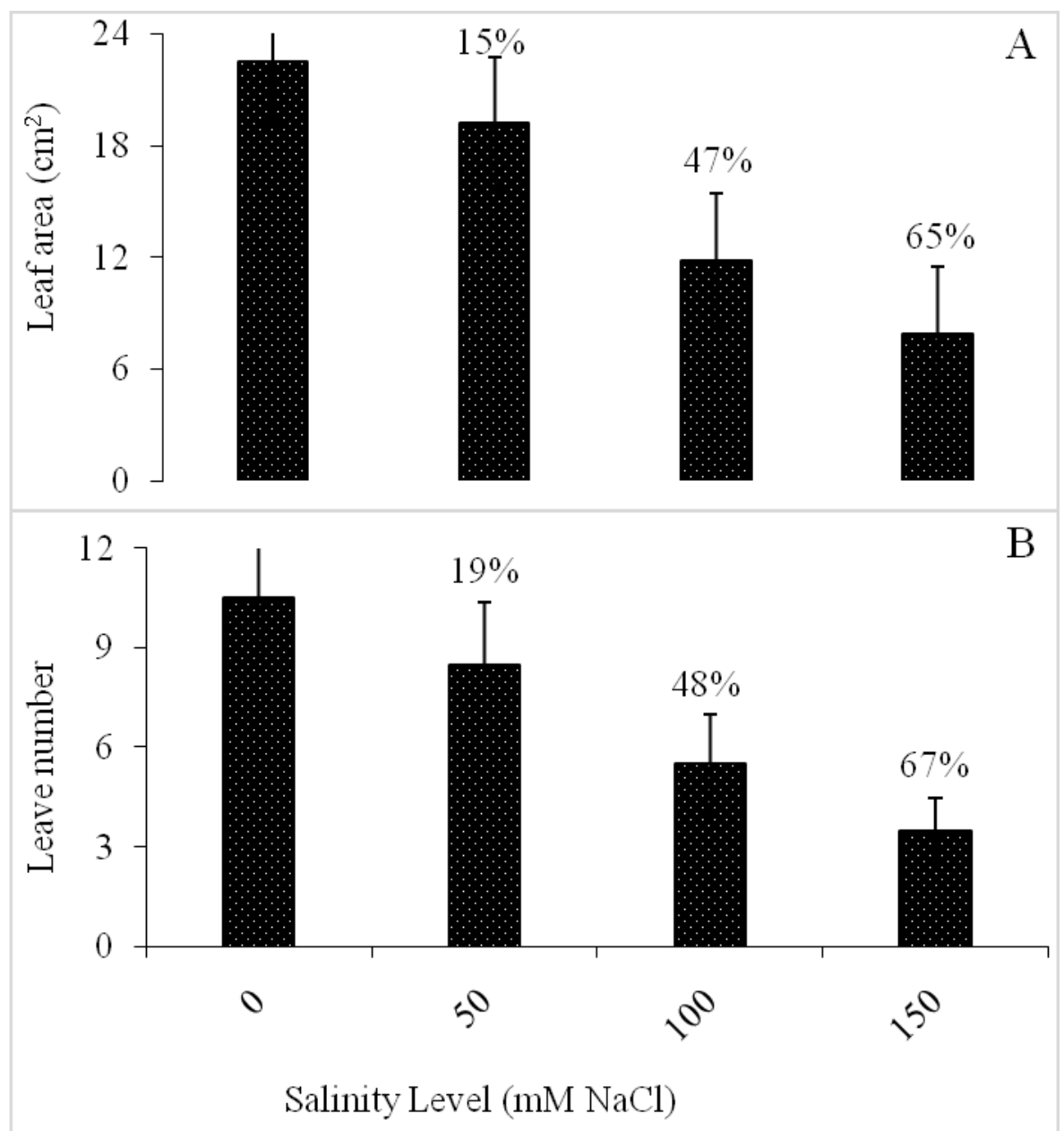

Figure 3 The effects of salinity treatments on (A) leaf area $\left(\mathrm{cm}^{2}\right)$ and (B) leaf number of pea plant. Each datum indicates mean value, and vertical lines on top of bars indicate standard error of means $(n=4)$. Values in parenthesis indicates the percent reduction from control.

In addition, the result reported that salinity stress significantly decreased aboveground biomass in pea plants in terms of shoot fresh and dry weight per plant. Nevertheless, the shoot dry weight was more strongly affected than shoot fresh weight. At a high salinity level $(150 \mathrm{mM} \mathrm{NaCl})$, the aboveground fresh weight decreased by $58 \%$ compared with control $(0 \mathrm{mM} \mathrm{NaCl})$, and likewise, aboveground dry weight decreased by $74 \%$ compared with control (Fig 4a, and b). Results regarding the salt tolerance index (STI) of pea plants showed that pea plants were able to deal with a low salinity level $(50 \mathrm{mM} \mathrm{NaCl})$, however as the salinity level increased, pea plants became more sensitive to salinity stress. As shown in the result. At $150 \mathrm{mM} \mathrm{NaCl}$, the salt tolerance index decreased by $73 \%$ as compared with control (Fig 4c.). 


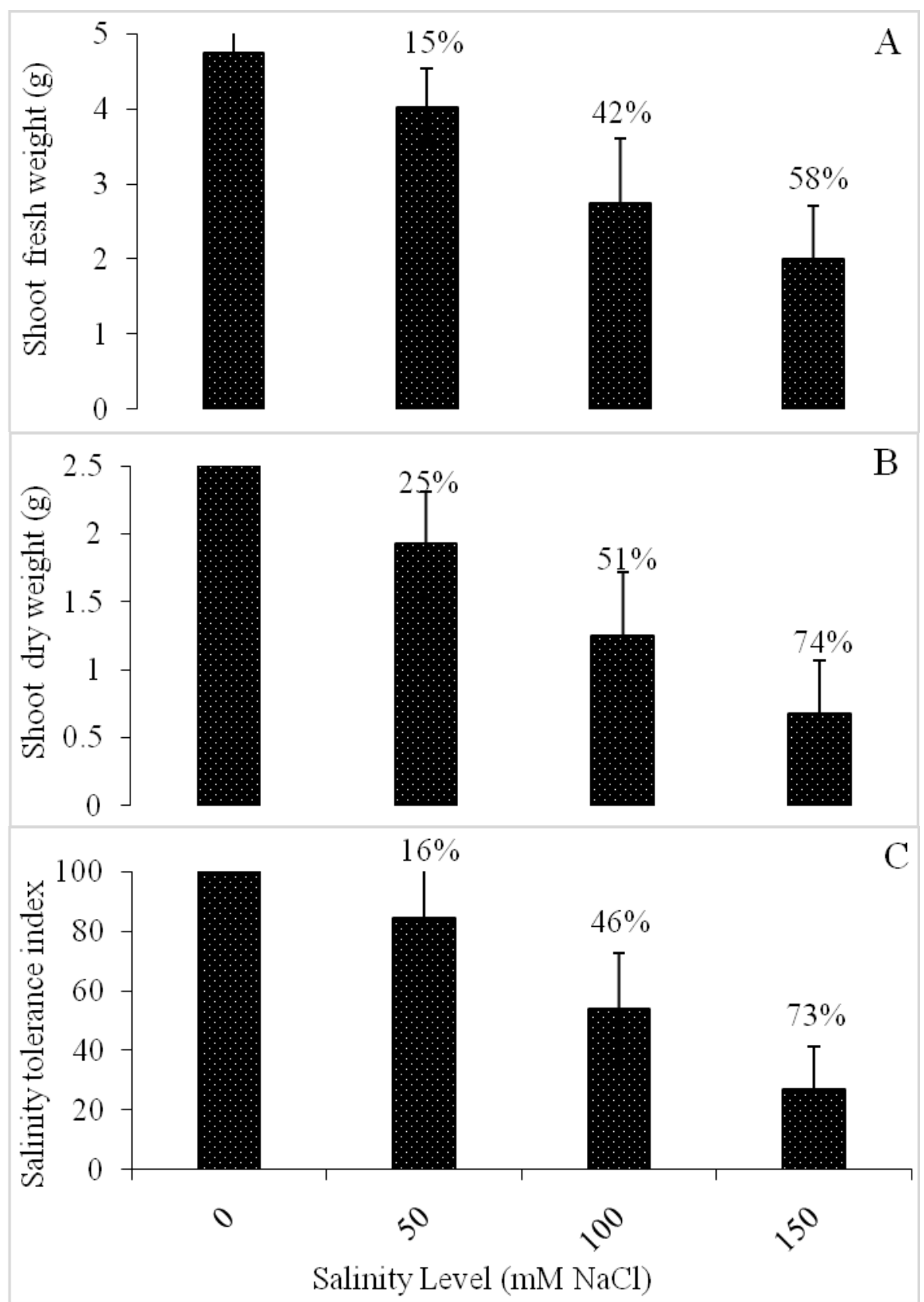

Figure: (4). The effects of salinity treatments on (A) shoot fresh weight (g), (B shoot dry weight (g) and (C) salinity tolerance index of pea plant. Each datum indicates mean value and vertical lines on top of bars indicate standard error of means $(n=4)$. Values in parenthesis indicates the percent reduction from control

\section{DISCUSSION}

In the present study, the adverse effect of salinity decreased germination and growth of pea plants as shown in Table 2. Germination and seedling stages are critical life stages for plant survival and appropriate seedling establishment, particularly under stress conditions. The findings of this study indicated that seeds germination and establishment of pea seedlings were inhibited gradually by increasing salinity stress. At a high salinity level of $150 \mathrm{mM} \mathrm{NaCl}$, seed germination was completely inhibited. In this respect, many studies reported that increasing salinity level decreased germination percentage and germination speed in field pea (Wolde and Adamu, 2018)), chick-pea (Ashraf and 
Waheed, 1992) wheat (Majid et al., 2013) and other legumes (Esechie, 1995; Morais et al., 2012; Piwowarczyk et al, 2016). Salinity delayed and prevented seed germination through various factors, for instance, a decrease in water uptake, changes in the mobilization of stored food, and disturbing the structural organization of proteins (Ibrahim, 2016). In addition, the present study showed that plant height, branch number, leaf number and area, fresh and dry biomass was severely reduced as salinity level increased and the death of plants was noticed at the high salinity concentration $(150 \mathrm{mM} \mathrm{NaCl})$ after 4 weeks of plant establishment. These results were consistent with previously published research (Grozeva et al., 2019). From the result of this study, it is evident that the toxicity in the salinity treatments is expressed more clearly in dry weight. This finding supports early findings which indicated that growth inhibition by $\mathrm{NaCl}$ treatments was greater for dry biomass production (Cordovilla et al, 1999; Hussain et al, 2002; López-Aguilar et al., 2003). The reduction of growth traits may be attributed to the osmotic effect of salinity stress which causes a decrease of growth promoters (Desoky et al., 2017). Also, the growth inhibition could be due to water deficit, ion toxicity, and nutrient imbalance due to the blockage of other nutrients such as $\mathrm{N}, \mathrm{P}, \mathrm{K}, \mathrm{Ca}$, and $\mathrm{NO}_{3}$ (Hasegawa et al., 2000). Other studies have shown similar result in pea plants (Grozeva et al., 2019), and other legumes plants such as pea plant (Hernandez et al., 1999), chick-pea (Ashraf and Waheed, 1992), and sesbania (Mahmood et al., 2008) when grown under salinity condition. The result showed a decreasing leaf number per plant, physiologically, salinity stress has a negative impact on many processes, however, the most significant effect is reducing cell division and expansion, which caused a reduction in leaf number. Moreover, the result herein pointed out that a high salinity level caused a reduction in leaf area, which may have resulted due to a reduction in cell division and cell extension. These results agree with another result that reported that salt stress causes a reduction in leaf surface expansion ratio, leading to the cessation of expansion as salt concentrations keep increasing (Wang and Nii, 2000).

\section{CONCLUSIONS}

Food productivity is decreasing due to the effect of various abiotic stresses. Cold, heat, salinity, and drought are among the major stresses, which adversely affect plants' growth and productivity. For that reason, reducing these losses is a main area of concern for all crop producers to manage increasing crop production. This study was aimed to investigate the impact of salinity stress on pea plants. The study showed that high salt stress inhibited and delayed seed germination and growth of pea plants. The study concluded that pea plants (Pisum sativum L.) are resistant to 50 and can withstand salinity at $100 \mathrm{mM} \mathrm{NaCl}$, but this cultivar is strongly sensitive to $150 \mathrm{mM} \mathrm{NaCl}$, and damages of salt-stress were significantly observed. However, plant growth was more sensitive to salt stress than germination. Future research must concentrate on molecular, physiological, and metabolic changes induced by salinity stress. Also, comprehensive information is required to understand the physiological responses of this plant under field conditions.

\section{ACKNOWLEDGMENT}

The authors are thankful to Mr. Yousef Alhersh for providing pea seeds. We also thank the Department of Plant Science, University of Zawia, for allowing us to use the laboratory equipment for this research.

\section{REFERENCES}

Abdel-Haleem A. \&El-Shaieny H. (2015). Seed germination percentage and early seedling establishment of five [Vigna unguiculata (L.) Walp.] genotypes under salt stress. European J. Exp. Biol., 5(2): 22-32 
Ashraf, M., \& Waheed, A. (1992). Screening chick-pea (Cicer arietinum L.) for salt tolerance. Der Tropenlandwirt-Journal of Agriculture in the Tropics and Subtropics, 93(1), 45-55.

Bhattacharjee, S. (2008). Triadimefon pretreatment protects newly assembled membrane system and causes up-regulation of stress proteins in salinity stressed Amaranthus lividus L. during early germination. J. Environ. Biol, 29(5), 805810.

Cheng, X., Deng, G., Su, Y., Liu, J. J., Yang, Y., Du, G. H., ... \& Liu, F. H. (2016). Protein mechanisms in response to $\mathrm{NaCl}$-stress of salt-tolerant and salt-sensitive industrial hemp based on iTRAQ technology. Industrial Crops and Products, 83, 444-452.

Chinnusamy, V., Jagendorf, A., \& Zhu, J. K. (2005). Understanding and improving salt tolerance in plants. Crop science, 45(2), 437-448.

Cokkizgin, A. (2013). Effects of Hydro and Osmo-Priming on seed Vigor of pea (Pisum sativum L). seed, 10, 100.

Cordovilla, M. D. P., Ligero, F., \& Lluch, C. (1999). Effect of salinity on growth, nodulation and nitrogen assimilation in nodules of faba bean (Vicia faba L.). Applied Soil Ecology, 11(1), 1-7.

Desoky, E. M., Merwad, A. M., \& Elrys, A. S. (2017). Response of pea plants to natural bio-stimulants under soil salinity stress. Am. J. Plant Physiol, 12, 28-37.

Esechie, H. A. (1995). Partitioning of chloride ion in the germinating seed of two forage legumes under varied salinity and temperature regimes. Communications in soil science and plant analysis, 26(19-20), 3357-3370.
Gairola, K. C., Nautiyal, A. R., \& Dwivedi, A. K. (2011). Effect of temperatures and germination media on seed germination of Jatropha curcas Linn. Advances in bioresearch, 2(2), 66-71.

Grozeva, S., Kalapchieva, S., \& Tringovska, I. (2019). Evaluation of garden pea cultivars to salt stress tolerance. Mechanization in agriculture \& Conserving of the resources, 65(4), 150-152.

Hasegawa, P. M., Bressan, R. A., Zhu, J. K., \& Bohnert, H. J. (2000). Plant cellular and molecular responses to high salinity. Annual review of plant biology, 51(1), 463-499.

Hayward, H. E., \& Wadleigh, C. H. (1949). Plant growth on saline and alkali soils. In Advances in Agronomy (Vol. 1, pp. 1-38). Academic Press.

Hernhdeza, J. A., Olmosa, E., Corpasb, F. J., Sevilla, F., \& de1 Riob, L. A. (1995). Saltinduced oxidative stress in chloroplasts of pea plants. Plant Science, 105(151167), 04047-8.

Hernandez, J. A., Campillo, A., Jimenez, A., Alarcon, J. J., \& Sevilla, F. (1999). Response of antioxidant systems and leaf water relations to $\mathrm{NaCl}$ stress in pea plants. New Phytologist, 141(2), 241-251.

Hubbard, M., Germida, J., \& Vujanovic, V. (2012). Fungal endophytes improve wheat seed germination under heat and drought stress. Botany, 90(2), 137-149.

Husen, A., Iqbal, M., \& Aref, I. M. (2016). IAAinduced alteration in growth and photosynthesis of pea (L.) plants grown under salt stress Pisum sativum. Journal of Environmental Biology, 37, 421-429.

Hussain, N., Mujeeb, F., Tahir, M., Khan, G. D., Hassan, N. M., \& Bari, A. (2002). Effectiveness of Rhizobium under salinity stress. Asian J Plant Sci, 1(1), 12-14. 
Ibrahim, E. A. (2016). Seed priming to alleviate salinity stress in germinating seeds. Journal of Plant Physiology, 192, 38-46.

Johnston, A. M., Tanaka, D. L., Miller, P. R., Brandt, S. A., Nielsen, D. C., Lafond, G. P., \& Riveland, N. R. (2002). Oilseed crops for semiarid cropping systems in the northern Great Plains. Agronomy Journal, 94(2), 231240.

Kaya, M. D., Ç İ Ftci, C. Y., \& Kaya, M. (2002). Bakteri Aşılaması ve Azot Dozlarının Bezelye (Pisum sativum L.)'de Verim ve Verim Öğelerine Etkileri.A.O. Ziraat. Fakültesi Tarım Bilimleri Dergisi 8(4): 300305.

Khan, H. A., Siddique, K. H., Munir, R., \& Colmer, T. D. (2015). Salt sensitivity in chickpea: growth, photosynthesis, seed yield components and tissue ion regulation in contrasting genotypes. Journal of plant physiology, 182, 1-12.

Konuşkan, Ö., Gözübenli, H., Atiş, İ., \& Atak, M. (2017). Effects of salinity stress on emergence and seedling growth parameters of some maize genotypes (Zea mays L.). Turkish Journal of Agriculture-Food Science and Technology, 5(12), 1668-1672.

López-Aguilar, R., Orduño-Cruz, A., LuceroArce, A., Murillo-Amador, B., \& TroyoDiéguez, E. (2003). Response to salinity of three grain legumes for potential cultivation in arid areas. Soil science and plant nutrition, 49(3), 329-336.

Mahajan, S., \& Tuteja, N. (2005). Cold, salinity and drought stresses: an overview. Archives of biochemistry and biophysics, 444(2), 139158.

Mahmood, A., Athar, M., Qadri, R., \& Mahmood, N. (2008). Effect of $\mathrm{NaCl}$ salinity on growth, nodulation and total nitrogen content in Sesbania sesban. Agriculturae

Conspectus

Scientificus, 73(3), 137-141.

Majid, A., Mohsen, S., Mandana, A., Saeid, J. H., Ezatollah, E., \& Fariborz, S. (2013). The effects of different levels of salinity and indole-3-acetic acid (IAA) on early growth and germination of wheat seedling. Journal of Stress Physiology \& Biochemistry, 9(4).

Martí, M. C., Florez-Sarasa, I., Camejo, D., Ribas-Carbó, M., Lázaro, J. J., Sevilla, F., \& Jiménez, A. (2011). Response of mitochondrial thioredoxin PsTrx o 1, antioxidant enzymes, and respiration to salinity in pea (Pisum sativum L.) leaves. Journal of Experimental Botany, 62(11), 3863-3874.

McKay, K., Schatz, B. G., \& Endres, G. (2003). Field pea production. NDSU Extension Service.

Morais, M. C., Panuccio, M. R., Muscolo, A., \& Freitas, H. (2012). Does salt stress increase the ability of the exotic legume Acacia longifolia to compete with native legumes in sand dune ecosystems?. Environmental and Experimental Botany, 82, 74-79.

Mujeeb-Kazi, A., Munns, R., Rasheed, A., Ogbonnaya, F. C., Ali, N., Hollington, P., ... \& Saddiq, M. S. (2019). Breeding strategies for structuring salinity tolerance in wheat. In Advances in Agronomy (Vol. 155, pp. 121-187). Academic Press.

Munns, R. (1993). Physiological processes limiting plant growth in saline soils: some dogmas and hypotheses. Plant, Cell \& Environment, 16(1), 15-24.

Munns, R. (2002). Comparative physiology of salt and water stress. Plant, cell \& environment, 25(2), 239-250.

Munns, R., \& Tester, M. (2008). Mechanisms of salinity tolerance. Annu. Rev. Plant Biol., 59, 651-681. 
Nasri, N., Kaddour, R., Rabhi, M., Plassard, C., \& Lachaal, M. (2011). Effect of salinity on germination, phytase activity and phytate content in lettuce seedling. Acta physiologiae plantarum, 33(3), 935-942..

Noreen, Z., \& Ashraf, M. (2009). Assessment of variation in antioxidative defense system in salt-treated pea (Pisum sativum) cultivars and its putative use as salinity tolerance markers. Journal of plant physiology, 166(16), 1764-1774.

Nuttonson, M. Y. (1961). The Physical Environment and Agriculture of Libya and Egypt with Special Reference to Their Regions Containing Areas Climatically and Latitudinally Analogous to Israel: A Study Based on Official Records, Material, and Reports of Various Agencies of the United Nations and Several National Administrations. American Institute of Crop Ecology.

Pandolfi, C., Mancuso, S., \& Shabala, S. (2012). Physiology of acclimation to salinity stress in pea (Pisum sativum). Environmental and Experimental Botany, 84, 44-51.

Piwowarczyk, B., Tokarz, K., \& Kamińska, I. (2016). Responses of grass pea seedlings to salinity stress in in vitro culture conditions. Plant Cell, Tissue and Organ Culture (PCTOC), 124(2), 227-240.

Rubio-Casal, A. E., Castillo, J. M., Luque, C. J., \& Figueroa, M. E. (2003). Influence of salinity on germination and seeds viability of two primary colonizers of Mediterranean salt pans. Journal of Arid Environments, 53(2), 145-154.

Sadak, M. S. (2016). Mitigation of salinity adverse effects on wheat by grain priming with melatonin. International Journal of Chem Tech Research, 9(2), 85-97.

Sarker, A., Hossain, M. I., \& Kashem, M. A. (2014). Salinity $(\mathrm{NaCl})$ tolerance of four vegetable crops during germination and early seedling growth. Int. J. Latest Res. Sci. Technol, 3(1), 91-95.

Schatz, B., \& Endres, G. (1999). Field pea production.

Wang, Y., \& Nii, N. (2000). Changes in chlorophyll, ribulose bisphosphate carboxylase-oxygenase, glycine betaine content, photosynthesis and transpiration in Amaranthus tricolor leaves during salt stress. The Journal of Horticultural Science and Biotechnology, 75(6), 623-627.

Wang, Q., Dodd, I. C., Belimov, A. A., \& Jiang, F. (2016). Rhizosphere bacteria containing 1-aminocyclopropane-1-carboxylate deaminase increase growth and photosynthesis of pea plants under salt stress by limiting $\mathrm{Na}+$ accumulation. Functional Plant Biology, 43(2), 161-172.

Wolde, G., \& Adamu, C. (2018). Impact of salinity on seed germination and biomass yields of field pea (Pisum sativum L.). Asian J. Sci. Tech, 9, 7565-7569.

Yan, S., Tang, Z., Su, W., \& Sun, W. (2005). Proteomic analysis of salt stress-responsive proteins in rice root. Proteomics, 5(1), 235244.

Yan, M. (2015). Seed priming stimulate germination and early seedling growth of Chinese cabbage under drought stress. South African Journal of Botany, 99, 88-92.

Zahran, H. H. (1999). Rhizobium-legume symbiosis and nitrogen fixation under severe conditions and in an arid climate. Microbiol. Mol. Biol. Rev., 63(4), 968-989. 


\title{
Pisum sativum L تأثير إجهاد الملوحة على إنبات ونمو نباتات البازلاء
}

\author{
امال احتيوش *، منيرة امساهل \\ قسم علم النبات، كلية العلوم، جامعة الزاوية، الزاوية، ليبيا
}

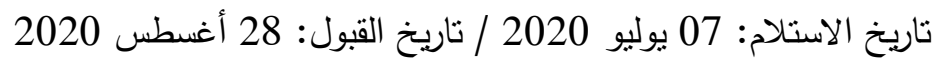
https://doi.org/10.54172/mjsc.v35i2.319:Doi

المستخلص: الهدف من الدراسة هو تقييم تاثيرات إجهاد الملوحة علي انبات ونمو نبات البازلاء. التجارب المعملية اجريت على

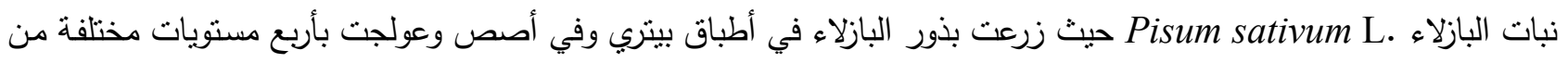
الملوحة (0 ، 50 ، 100 ، و 150 ملي مولار من كلوريد الصـوديوم). نفذت التجارب وفق التصميم العشوائي الكامل بأربعـة مكررات. أظهرت النتائج أن بذور البازلاء كانت قادرة على الإنبات عند مسنويات ملوحة منخفضـة (50 ملي مولار من كلوريد

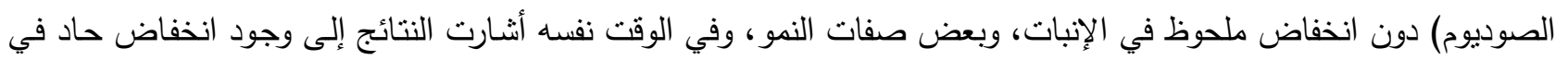

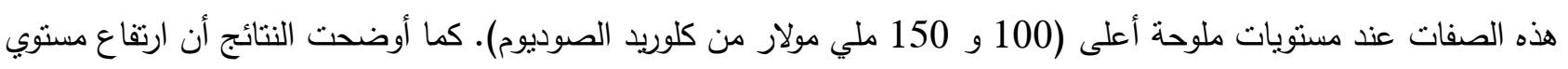

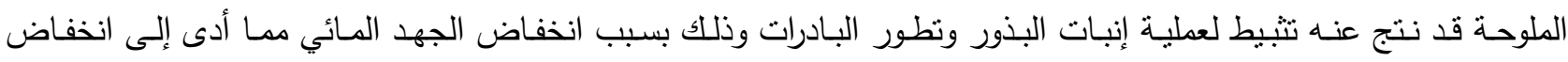
امنصـاص المساء بواسطة البذور • وتم منع إنبات البذور بسبب مستوى عالٍ من إجهاد الملوحة (150 ملي مولار من كلوريد

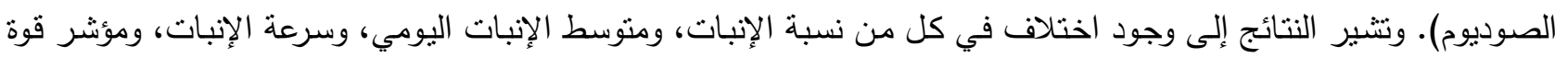
البادرة تحت مستويات الملوحة المتوسطة والعالية. كما تشير النتائج إلى انخفاض جميع الصفات المدروسة بزيادة نركيز محلول كلوريد الصوديوم. حيث سجلت النتائج أن الحد الأقصى لكل من نسبة الإنبات، ومتوسط الإنبات اليومي، وسرعة الإنبات، ومؤشر قوة البادرة كانت تحت ظروف (0 ملي مولار من كلوريد الصوديوم) والحد الادنى الصفات نفسها كان عند أعلى مستوى للملوحة

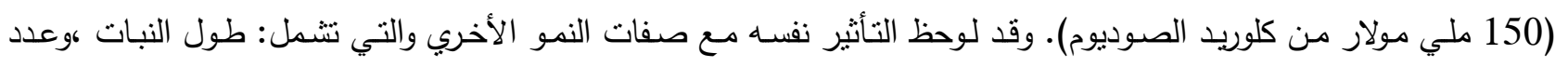

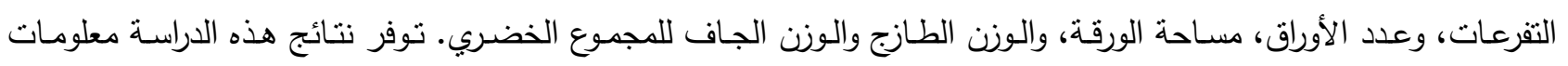

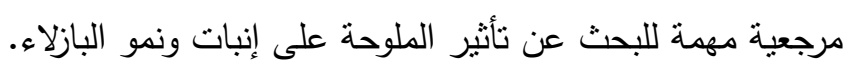

(الكلمات المفتاحية: البازلاء(Pisum sativum L)؛، الإجهاد الملحي، الإنبات، النمو، مؤشر قوة البادرة. 